\title{
Incidental catch of seabirds in Newfoundland and Labrador gillnet fisheries, 2001-2003
}

\author{
Steven Benjamins ${ }^{1,3, *}$, David W. Kulka ${ }^{2}$, Jack Lawson ${ }^{2}$ \\ ${ }^{1}$ Whale Research Group, Biology Annex, Memorial University of Newfoundland, 297 Mt. Scio Road, St. John's, \\ Newfoundland and Labrador A1B 3V6, Canada \\ ${ }^{2}$ Fisheries and Oceans Canada, PO Box 5667, St. John's, Newfoundland and Labrador A1C 5X1, Canada \\ ${ }^{3}$ Present address: Joint Nature Conservation Committee, Monkstone House, City Road, Peterborough, \\ Cambridgeshire PE1 1JY, UK
}

\begin{abstract}
Incidental catch of seabirds in gillnet fisheries in Newfoundland and Labrador, Canada, has been identified in several fisheries, but defendable estimates are unavailable. Despite reduced fishing effort in several fisheries, concern remains that catch rates might negatively impact local seabird populations. Based on data sources within Fisheries and Oceans Canada (St. John's, Canada), total numbers of incidentally caught seabirds in nearshore and offshore Newfoundland waters were estimated for the years 2001, 2002 and 2003. Incidental catch rates were derived using net-days as measures of effort, with fishing trips as sampling units. Confidence intervals were estimated using resampling techniques. Most reports originated from the nearshore gillnet fishery for Atlantic cod Gadus morhua, although many birds were captured in other fisheries. The most commonly captured seabirds were murres Uria sp. and shearwaters (genera Calonectris and Puffinus), although other species were also captured in smaller numbers. As many as 2000 to 7000 murres, over 2000 shearwaters (various species), and tens to hundreds of northern fulmars Fulmarus glacialis, gannets Morus bassanus, double-crested cormorants Phalacrocorax auritus, loons (genus Gavia), eider ducks Somateria mollissima, razorbills Alca torda, puffins Fratercula arctica, black guillemots Cepphus grylle and dovekies Alle alle were estimated to have been captured annually in the area during the period 2001 to 2003, although catches varied considerably from year to year. Populations of these species are not presently thought to be declining due to this incidental mortality; however, present catch levels may contribute to limited growth in these populations, and populations might be affected if fishing effort were to increase.
\end{abstract}

KEY WORDS: Incidental catch · Seabirds · Newfoundland and Labrador · Canada • Murres · Shearwaters

\section{INTRODUCTION}

The shores and waters of Newfoundland and Labrador (Canada) are important to many seabirds as feeding and breeding grounds, migration corridors, and wintering areas (Brown et al. 1975, Huettmann \& Diamond 2000). Species frequenting these waters include 2 species of loons (common loon Gavia immer and red-throated loon $G$. stellata), the northern fulmar Fulmarus glacialis, 5 species of shearwaters (Cory's shearwater Calonectris diomedea, greater shearwater Puffinus gravis, sooty shearwater P. griseus, Manx shearwater $P$. puffinus, and Audubon's shearwater $P$. lherminieri), 2 species of storm petrels (Leach's stormpetrel Oceanodroma leucorhoa and Wilson's stormpetrel Oceanites oceanicus), the northern gannet Morus bassanus, 2 species of cormorants (great cormorant Phalacrocorax carbo and double-crested cormorant $P$. auritus), marine ducks (family Anatidae), shorebirds (family Charadriidae), gulls, terns and 
jaegers (family Laridae), and 6 species of alcids (family Alcidae, razorbill Alca torda, common murre Uria aalge, thick-billed murre U. lomvia, dovekie Alle alle, black guillemot Cepphus grylle, and Atlantic puffin Fratercula arctica; Snow 1996, Mactavish et al. 2003). Several large seabird colonies of regional or global significance, e.g. Leach's storm petrels, northern fulmars, gannets, Atlantic puffins and common murres, lie within provincial boundaries (Brown et al. 1975, Montevecchi \& Tuck 1987; our Fig. 1).

Entanglement in fishing gear is a significant source of incidental mortality for many seabird species worldwide and has brought some close to extinction (Brothers et al. 1999, FAO 1999, Tasker et al. 2000, Montevecchi 2001). Globally, hundreds of thousands of seabirds are killed annually in pelagic and bottom-set longlines (Brothers et al. 1999, Cooper et al. 2000, Tuck et al. 2003, Gilman et al. 2005), pelagic driftnets (Carretta et al. 2004, Uhlmann et al. 2005) and pelagic and bottom-set gillnets (Piatt et al. 1984, Piatt \& Nettleship 1987, Melvin et al. 1999, Österblom et al. 2002). Seabirds are typically longlived, mature late in life, and exhibit low fecundity; thus, populations are vulnerable to anthropogenic mortality, such as occurs through incidental catch in fisheries (Furness 2003. Lewison et al. 2005). This incidental mortality, or bycatch, has been recognised as a potentially significant conservation concern (FAO 1999, Lewison et al. 2005).

Many authors have commented on the problem of incidental mortality of seabirds in Newfoundland and Labrador fisheries (e.g. Piatt et al. 1984, Piatt \& Nettleship 1987, Chapdelaine 1997, Bakken \& Falk 1998, Brothers et al. 1999, Chardine et al. 2000, Cooper et al. 2000, Anonymous 2003, Davoren 2007). Past reports of bycatch of seabirds, particularly alcids, in Newfoundland gillnets typically involved the fishery for Atlantic cod Gadus morhua (Piatt et al. 1984, Piatt \& Nettleship 1987, Chapdelaine 1997). This fishery was historically important, but widespread fisheries closures in 1992 and 1993 due to declines in cod stocks reduced fishing effort considerably (Hutchings \& Myers 1995, Sinclair \& Murawski 1997). These moratoria likely led to an indirect reduction in seabird mortality (Robertson et al. 2004). However, gill- nets have remained in use in other fisheries such as those targeting lumpfish Cyclopterus lumpus, Greenland halibut Hippoglossoides platessoides and monkfish Lophius americanus; in addition, nearshore cod fisheries have been intermittently reopened on a limited scale from 1997 onward (Table 1).

Most recent studies on seabird bycatch in Newfoundland waters have focused on longline fisheries (Brothers et al. 1999, Cooper et al. 2000, Kulka \& Showell 2000, Anonymous 2003; however, see Davoren 2007) for a recent assessment of common murre net mortality in gillnets off northeastern Newfoundland). Continued reports of bycatch of seabirds in gillnets by fishers, Fishery Observers (DFO, NL; see below) and scientists suggest the need for more comprehensive estimates of seabird mortality in Newfoundland and Labrador gillnet fisheries. Here, we review existing data from multiple sources to provide initial estimates of seabird bycatch in 8 commercial gillnet fisheries in Newfoundland and Labrador.

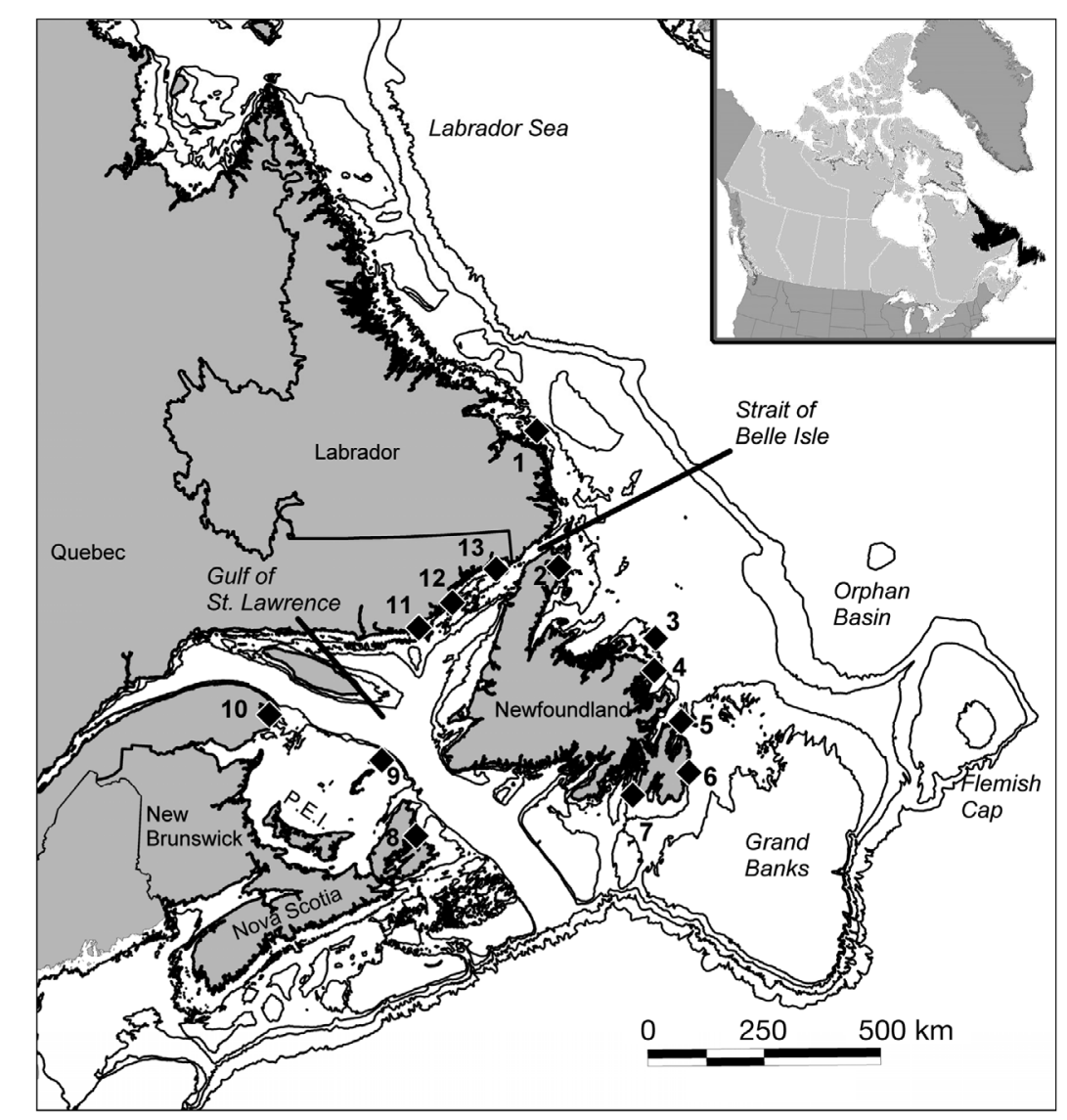

Fig. 1. Overview of waters around Newfoundland and Labrador, Canada, including important seabird colonies in the area $(\bullet)$. 1: Gannet Islands; 2: Hare Bay; 3: Funk Island; 4: Cabot Islands; 5: Baccalieu Island; 6: Witless Bay; 7: Cape St. Mary's; 8: Bird Island; 9: Rocher aux Oiseaux; 10: Ile de Bonaventure/Rocher Percé; 11: Sainte-Marie Islands; 12: Gros Mécatina; 13: Baie de Brador; P.E.I.: Prince Edward Island. 100, 200, 1000 and $2000 \mathrm{~m}$ depth contours indicated 
Table 1. Total landed catches and estimated net-day effort for various Newfoundland and Labrador gillnet fisheries in 2001, 2002 and 2003

\begin{tabular}{|c|c|c|c|c|c|c|}
\hline \multirow[t]{2}{*}{ Fishery } & \multicolumn{3}{|c|}{$\begin{array}{c}\text { Total catch } \\
\text { (mt round weight) }\end{array}$} & \multicolumn{3}{|c|}{$\begin{array}{c}\text { Fishing effort } \\
\text { (1000 net-days, estimated) }\end{array}$} \\
\hline & 2001 & 2002 & 2003 & 2001 & 2002 & 2003 \\
\hline Cod (nearshore) & 10264 & 10233 & 6284 & 907 & 1074 & 793 \\
\hline Cod (offshore) & 1394 & 1913 & 1780 & 14 & 22 & 18 \\
\hline Lumpfish (nearshore) & 872 & 171 & 554 & 218 & 123 & 126 \\
\hline Herring (nearshore) & 1430 & 1660 & 1025 & 32 & 23 & 14 \\
\hline Monkfish/skate (offshore) & 942 & 3027 & 2659 & 154 & 252 & 212 \\
\hline White hake (offshore) & 305 & 345 & 278 & 6 & 12 & 10 \\
\hline Greenland halibut (nearshore) & 1687 & 868 & 1321 & 417 & 316 & 1696 \\
\hline Greenland halibut (offshore) & 7237 & 5277 & 3517 & 2564 & 2136 & 6675 \\
\hline Redfish (nearshore/offshore) & 447 & 337 & 486 & 82 & 23 & 68 \\
\hline Winter flounder (nearshore) & 504 & 340 & 205 & 31 & 80 & 65 \\
\hline
\end{tabular}

\section{MATERIALS AND METHODS}

Data used to derive bycatch estimates of seabirds for 2001-2003 were derived from 2 sources: Fishery Observers deployed to commercial fishing vessels contracted to DFO, NL (Department of Fisheries and Oceans, Newfoundland and Labrador Region) and Bycatch Collectors, an existing network of selected commercial fishers. Fishery Observers were independent recorders of detailed fishing catch and effort, assigned to fisheries as required under existing management regulations (Kulka \& Firth 1987). Bycatch Collectors were fishers recruited by the Marine Mammal Section of DFO, NL to report incidental catch and associated fishing effort in their commercial fisheries.

Both Bycatch Collectors and Fishery Observers reported bycatch of seabirds as well as fish, invertebrates and marine mammals and reptiles, captured during fishing operations. Fishery Observers received training in seabird identification and were equipped with identification guides, while Bycatch Collectors received comparable identification materials from DFO. Despite these aides, carcass decomposition and/or lack of observer knowledge precluded identification of some birds to species.

All fisheries effort data were organized geographically based on Northwest Atlantic Fisheries Organization (NAFO) Divisions of Newfoundland waters (Table 1, Fig. 2). In the present study, 'nearshore' fisheries were defined as those occurring in NAFO units immediately adjacent to land, whereas 'offshore' fisheries occurred in NAFO units further from land (Fig. 2 inset). Generally, Bycatch

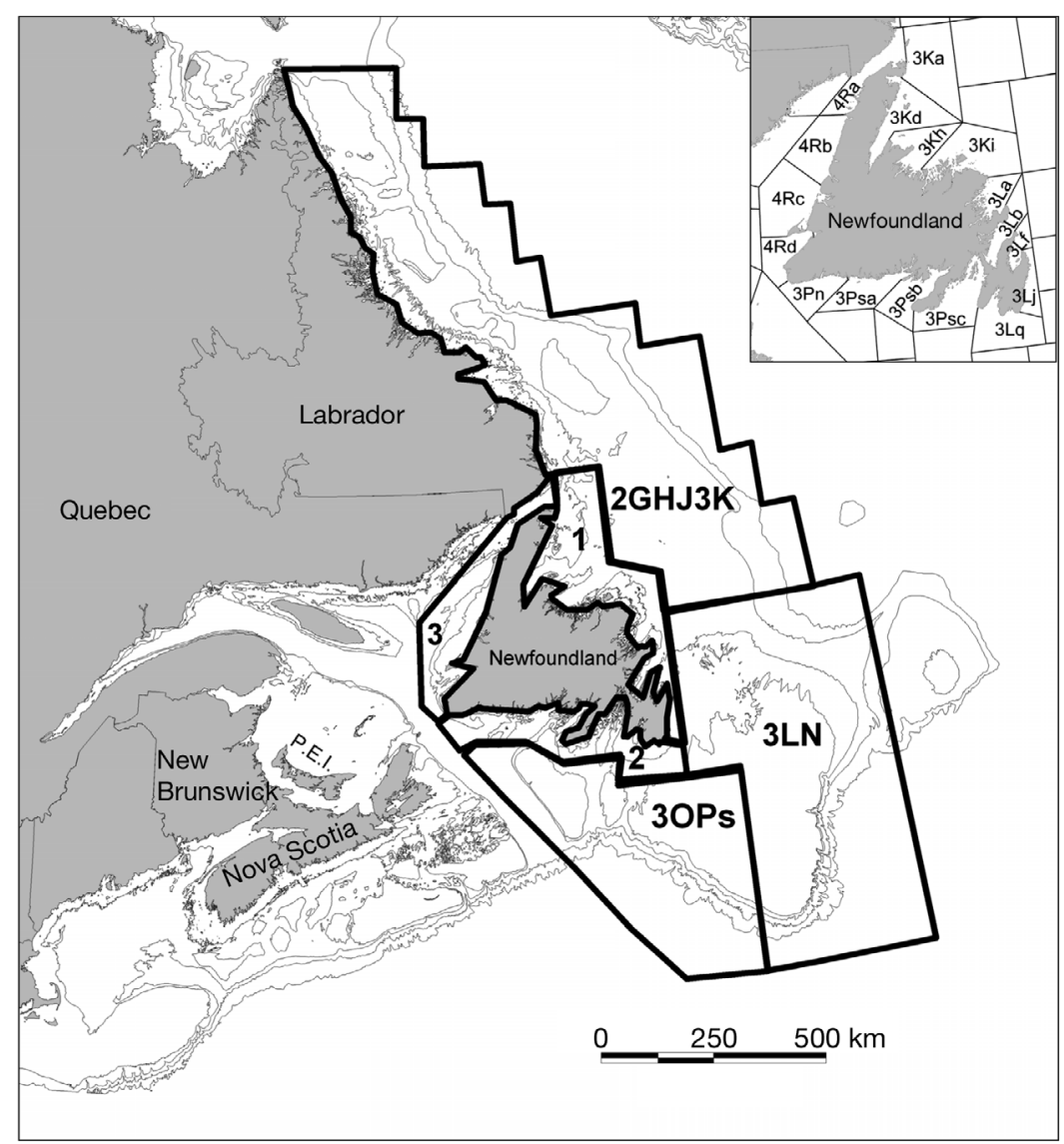

Fig. 2. Geographical aggregations of fishing effort data and incidental catches of seabirds in nearshore and offshore Newfoundland and Labrador waters. 1: northeast coast; 2: south coast; 3: west coast; P.E.I.: Prince Edward Island. Offshore fisheries 2GHJ3K and 3LN and nearshore NAFO units (inset) are discussed in 'Materials and methods' 
Collectors fished in nearshore waters, while Fishery Observers monitored larger vessels further offshore. We studied nearshore gillnet fisheries for Atlantic cod, lumpfish, Atlantic herring Clupea harengus, redfish Sebastes sp., Greenland halibut, and winter flounder Pseudopleuronectes americanus, and analyzed these using Bycatch Collector data where possible. Because of low Fishery Observer coverage in nearshore fisheries, we only used Observer data when Bycatch Collector data were unavailable. We studied offshore gillnet fisheries for Atlantic cod, monkfish, skates (Rajidae), white hake Urophycis tenuis, redfish, and Greenland halibut, using Fishery Observer data. Observer coverage levels varied greatly between fisheries, from year to year, and also between Bycatch Collectors and Fishery Observers (Tables 2 \& 3).

Gillnet fisheries for Atlantic cod, lumpfish, and winter flounder were widespread in nearshore waters throughout the island of Newfoundland and southern Labrador; cod fisheries along the northeast and west coasts of Newfoundland were closed in 2003 due to conservation concerns (Table 1). Offshore fisheries for cod occurred only on the southern Grand Banks (NAFO Division 3Ps). Gillnet fisheries for herring and redfish were concentrated along the northwest coast (NAFO unit
4Ra), and the south and southwest coasts (NAFO units 3Pn/3Psa and adjacent offshore sections of Division 3Ps), respectively. Offshore fisheries for white hake, monkfish, and skates were concentrated along the shelf edge of the southwestern Grand Banks (NAFO Divisions 3OPs), while offshore fisheries for Greenland halibut occurred along the shelf edge from the southern Grand Banks to northern Labrador (Fig. 1). Nearshore fisheries for Greenland halibut took place locally wherever deep waters $(>200 \mathrm{~m})$ occurred close to shore (particularly in NAFO units 3Ki, 3Psb and 4Rb; Fig. 2 inset). Gillnets used in these gillnet fisheries varied according to mesh size, length, deployment depth and deployment duration. Details of nets used in different fisheries are summarized in Table 2.

The bycatch rate $R$ for each species in each fishery was calculated as follows:

$$
R=\text { no. of events/no. of net-days, }
$$

where 1 net-day equates to 1 net (of standard length, typically $91 \mathrm{~m}$ ) fishing for $24 \mathrm{~h}$. 'Number of events' was based on individual records of capture events by Bycatch Collectors and Fishery Observers. In the case of herring fisheries where smaller nets are used, incidental catch rates were extrapolated to greater net lengths

Table 2. Typical features of gillnet fisheries in Newfoundland and Labrador

\begin{tabular}{|c|c|c|c|c|c|c|}
\hline Fishery & $\begin{array}{l}\text { No. of nets } \\
\text { per fisher }\end{array}$ & $\begin{array}{l}\text { Standard net } \\
\text { length }(\mathrm{m})\end{array}$ & $\begin{array}{l}\text { Mesh size } \\
\quad(\mathrm{cm})\end{array}$ & $\begin{array}{c}\text { Deployment } \\
\text { depth }(\mathrm{m})\end{array}$ & $\begin{array}{l}\text { Deployment } \\
\text { time (d) }\end{array}$ & Active fishery \\
\hline Atlantic cod & $3-40$ & 91 & 14 & $20-220$ & $1-2$ & All year \\
\hline Lumpfish & $10-50$ & 91 & 25 & $5-50$ & $3-4$ & May-June \\
\hline Atlantic herring & $1-10$ & 32 & 6 & 2-40 (pelagic) & 1 & All year \\
\hline Monkfish/skates & $10-35$ & 91 & 30 & $100-350$ & $1-2$ & Summer \\
\hline White hake & $8-30$ & 91 & 14 & $100-300$ & $1-2$ & Summer \\
\hline Greenland halibut & $3-70$ & 91 & 15 & $200-1300$ & $2-18$ & All year \\
\hline Redfish & $3-30$ & 91 & 14 & $100-500$ & $1-7$ & All year \\
\hline Winter flounder & $1-10$ & 91 & 16.5 & $5-50$ & $1-3$ & All year \\
\hline
\end{tabular}

Table 3. Fractions of total fishing effort (net-days) for all areas combined per year. nd: no data (no Bycatch Collector or Fishery Observer data available)

\begin{tabular}{|c|c|c|c|c|c|c|}
\hline \multirow[t]{2}{*}{ Fishery } & \multicolumn{3}{|c|}{$\begin{array}{l}\text { Bycatch Collector reported } \\
\text { fraction of net-days (\% of total) }\end{array}$} & \multicolumn{3}{|c|}{$\begin{array}{c}\text { Fishery Observer reported } \\
\text { fraction of net-days (\% of total) }\end{array}$} \\
\hline & 2001 & 2002 & 2003 & 2001 & 2002 & 2003 \\
\hline Cod (nearshore) & 0.7 & 0.8 & 0.9 & 0.5 & 0.4 & 0.5 \\
\hline Cod (offshore) & nd & nd & nd & 5.4 & 3.8 & 5.5 \\
\hline Lumpfish (nearshore) & 10.2 & 10.4 & 12.6 & 0.8 & 1.2 & 1.7 \\
\hline Herring (nearshore) & 2.0 & 2.8 & 7.9 & 0.1 & nd & nd \\
\hline Monkfish/skate (offshore) & 1.7 & 0.5 & 0.1 & 16.3 & 36.2 & 29.7 \\
\hline White hake (offshore) & nd & nd & nd & 7.1 & 16.6 & 14.9 \\
\hline Greenland halibut (nearshore) & 0.8 & 0.8 & 0.3 & 2.0 & 1.3 & 0.1 \\
\hline Greenland halibut (offshore) & nd & nd & nd & 4.0 & 6.8 & 0.7 \\
\hline Redfish (nearshore/offshore) & 0.5 & 2.2 & nd & 0.4 & 2.8 & 1.2 \\
\hline Winter flounder (nearshore) & 0.3 & 0.4 & 0.9 & 0.5 & 0.2 & 0.2 \\
\hline
\end{tabular}


used in other fisheries. All analyses used individual fishing trips of fishers as sampling units. Bycatch Collectors reported the total number of individual birds in their data record, while Fishery Observers recorded total weight of caught birds. The latter dataset was analyzed using total weight, and subsequently converted to an estimated minimum number of birds using published body mass values (e.g. Ainley et al. 2002).

Using DFO fisheries log records obtained from the Policy and Economics Branch, DFO, NL, the amount of fishing effort $E$ was estimated for individual fisheries occurring within predefined geographical and temporal limits. The total incidental catch estimate $N$ was then calculated by:

$$
N=E \times R
$$

Wherever possible, 95\% confidence intervals (CI) for these estimates were calculated using resampling software, to take into account uncertainty associated with these data (Blank et al. 2001). Bootstrapping from the observed distribution of incidental catch rates (1000 times) produced a distribution of catch rates, against which the original catch rate $R$ could be evaluated. The 2.5 and 97.5 percentile of this distribution then represented the lower and upper borders of the $95 \%$ confidence interval surrounding $R$. We did not calculate CI in cases where insufficient data were available ( $\mathrm{n}<20$ trips).

Bycatch estimates in nearshore fisheries were calculated based on geographical area (3 coastlines of the island of Newfoundland: northeast, south, and west; Fig. 2) and time of year (4 quarters where relevant, depending on the fishery: January-March, AprilJune, July-September, and October-December). Only limited Fishery Observer data were available for the west coast (NAFO Division 4R). Gillnet fishing is limited in nearshore waters of Labrador, and this region is underrepresented in data collection efforts. We therefore excluded this area from further analysis.

For offshore fisheries, we stratified data geographically based on a combination of oceanographic and NAFO jurisdictional boundaries (Fig. 2)

- 2GHJ3K (subarctic waters off Labrador and northeastern Newfoundland, characterized by a relatively narrow continental shelf, influenced by the Labrador Current)

- 3LN (cold temperate waters of the eastern and northeastern part of the Grand Banks, characterized by a wide continental shelf, influenced by the Labrador Current)

- 3OPs (temperate waters of the southern and southwestern part of the Grand Banks, characterized by a wide continental shelf, influenced by the North Atlantic Current).

For most nearshore fisheries, bycatch estimation analyses were performed at the geographic scale of coastlines, because non-breeding seabirds are unlikely to either restrict themselves to a single NAFO unit or be distributed uniformly around the island of Newfoundland. Also, management regimes for nearshore fisheries in the area are typically established at this scale. An analysis at a smaller geographic scale was performed for several species of colonially nesting seabirds with limited foraging ranges $(<100 \mathrm{~km})$. Species analyzed at this scale included gannets, common murres, Atlantic puffins, and razorbills. Although these species are highly mobile and wide-ranging, their distribution is restricted during spring and summer, with adult birds foraging near breeding grounds (Cairns et al. 1987, Piatt \& Nettleship 1987, Huettmann \& Diamond 2000, Davoren et al. 2003a,b). Fisheries operating near breeding colonies were considered more likely to negatively impact on these species than more distant fisheries. We therefore estimated incidental catches of these species at the smallest possible geographical scale of individual NAFO units (Fig. 2, inset) before summing estimates. This prevented high bycatch rates in waters near breeding colonies from artificially elevating bycatch estimates in other areas where birds might be less abundant. Where bird colonies were located near the border between 2 NAFO units, fishing effort data from both adjacent units were used. This method may have underestimated bycatch of these species due to lack of observer coverage in some areas.

\section{RESULTS}

An array of seabird species was reported as bycatch by both Bycatch Collectors and Fishery Observers (Tables 4 \& 5). Bycatch Collectors most often reported catches of murres Uria sp. These catches were most often reported from nearshore cod and lumpfish fisheries, particularly in the immediate vicinity of colonies such as Funk Island and Cabot Islands (NAFO units 3Ki/3La) and Cape St. Mary's (NAFO units 3Lq/ 3Psc).Two murres were reported by a Bycatch Collector in 2001 in the nearshore Greenland halibut fishery in NAFO unit 3La (Table 4). Some Bycatch Collectors reported small numbers of other seabird species including black guillemots, razorbills, gannets, doublecrested cormorants, sooty shearwaters and loons (Table 4). No seabirds were reported by Bycatch Collectors in the nearshore herring or redfish fishery.

Fishery Observers were concentrated on larger vessels further offshore and accordingly reported more oceanic species such as fulmars and shearwaters (Table 4). However, Observers monitored a limited amount of nearshore fishing effort, and reported bycatch of loons, gannets, cormorants, shearwaters, 


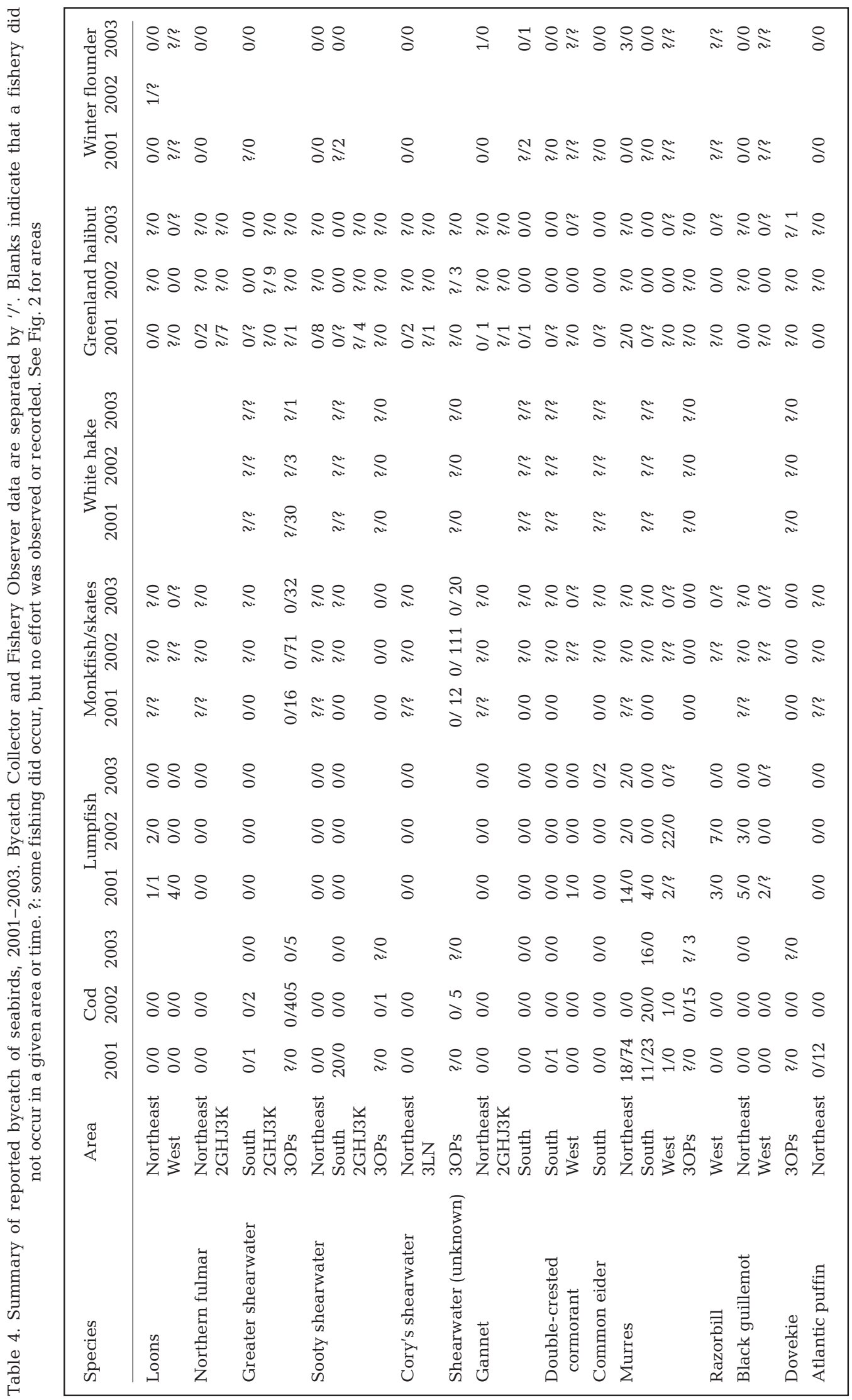




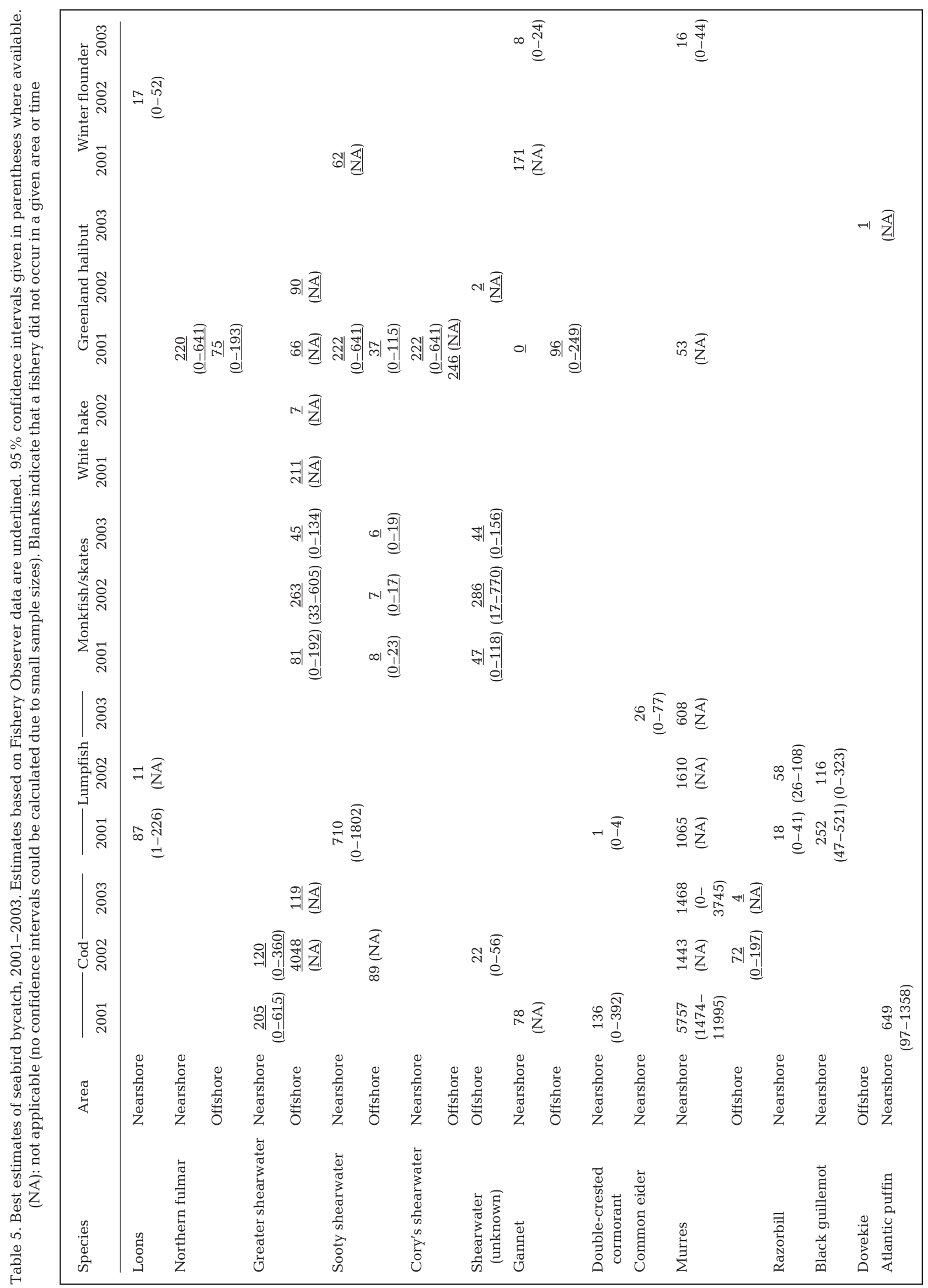


common eider, murres and puffins (Table 4). As with the Bycatch Collector data, capture of colonially breeding birds such as murres and puffins appeared to be geographically localized, and correlated with the proximity to a breeding colony. On most trips only small numbers of birds were captured, but occasionally large numbers of murres and shearwaters were reported. Shearwaters were the most commonly reported species in offshore fisheries, particularly those targeting cod, monkfish and skates and white hake. Most cases involved greater shearwaters and unidentified shearwaters, although sooty and Cory's shearwaters were also reported. Loons, gannets, cormorants, eiders, puffins and dovekies were only rarely captured (Table 4). Fishery Observers reported no seabirds in the redfish fishery.

Final bycatch estimates varied greatly among bird species. Species such as eider ducks, double-crested cormorants, Cory's shearwaters, gannets, puffins, and dovekies were only caught in small numbers between 2001 and 2003. Loons, black guillemots, razorbills, northern fulmars and sooty shearwaters were caught more regularly, while the most commonly captured species were murres and greater shearwaters, as well as unidentified shearwaters (Table 5). These species also occurred in the widest range of fishing gears, reflecting their wide distribution. Murres were captured in large numbers (thousands) near all colonies during summer, as well as occasionally (hundreds) on the Grand Banks during winter (Table 5). On average, several hundred to several thousand shearwaters of various species may have been captured each year, particularly along the southwestern edge of the Grand Banks, in fisheries targeting cod, monkfish, skates and white hake (Table 5).

\section{DISCUSSION}

The present study represents the first attempt at estimating bycatch of seabirds in 8 different gillnet fisheries throughout Newfoundland and Labrador waters since the 1992 cod moratorium. Risk of entanglement varies between species, and depends on abundance, feeding behaviour, diving capacity and behaviour around fishing vessels. Seabirds that routinely dive deep (e.g. shearwaters and alcids) are at greater risk of encountering bottom-set gillnets (Piatt \& Nettleship 1985, Burger \& Simpson 1986, Jury 1986, Cairns 1992, Keitt et al. 2000, Burger 2001, Montevecchi 2001, Lowther et al. 2002, Montevecchi \& Stenhouse 2002). However, birds may also have been captured as nets were set or hauled, in which case they may have swum into the nets by accident, or attempted to feed on entangled fish or discards near the fishing vessel
(Camphuysen et al. 1995, Tasker et al. 2000). Finally, some birds that have died through unrelated causes may subsequently be swept into nets. Some birds in our study were reported in nets fishing at depths beyond their known diving range (particularly the Greenland halibut and monkfish/ skate fisheries), making capture near the surface during handling of nets more probable.

The majority of reported catches in nearshore fisheries involve murres. Annual bycatch of murres for the entire area is difficult to determine, due to incomplete coverage by Fishery Observers and Bycatch Collectors of all waters surrounding breeding colonies. Furthermore, catches may vary considerably from year to year within the same region, and even among fishers within a region. The occasional capture of large numbers of murres in trips using comparatively little fishing effort can strongly influence the final estimate. Associated CI are often considerable, indicating high levels of uncertainty. Nonetheless, as many as 2000 to 7000 murres may be caught annually in various nearshore gillnet fisheries in Newfoundland and Labrador waters (Table 5). In contrast, Piatt \& Nettleship (1987) reported an annual average of 22070 common murres caught near 4 major Newfoundland seabird colonies during the period 1981 to $1984,81 \%$ of which were caught in the cod gillnet fishery, which was still widespread at the time. As such, the present data indicate that incidental mortality of common murres in gillnets continues, despite limited fishing effort, but at smaller absolute numbers than recorded historically. Schools of capelin Mallotus villosus, an important prey species of both murres and cod, are patchily distributed, leading to clustering of murres in areas of high capelin density (Davoren et al. 2003a, Davoren 2007). Such areas may be targeted by fishers fishing for cod, which could increase the likelihood of many murres being captured at once in relatively few gillnets (Piatt \& Nettleship 1987, Robertson et al. 2004). Other alcids, such as black guillemots, razorbills and Atlantic puffins, are apparently less often captured in gillnets. Puffins also feed in aggregations but are smaller than murres and may therefore not become entangled in cod or lumpfish gillnets as easily. Razorbills are relatively uncommon in this area and so are less likely to occur as bycatch. Black guillemots do not cluster in feeding aggregations and do not breed in colonies, limiting the potential for large numbers to be caught at once (Brown et al. 1975).

On their own, effects of bycatch on the common murre population of Newfoundland and Labrador appear to be limited. The Newfoundland breeding population is estimated at $>500000$ pairs, of which $>400000$ nest on Funk Island, 150000 in the Witless Bay area, and 10000, 4000 and 2600 at Cape St. 
Mary's, on Baccalieu Island and on Cabot Island, respectively (CWS 2004; Fig. 1). In the present study, almost all birds were reported captured in nets fishing for Atlantic cod and lumpfish near breeding colonies; catch estimates in these areas can be high in some years (Davoren 2007). For example, the 2001 bycatch estimate of 2648 murres (95\% CI: 0 to 6674) in the 3Lq/3Psc nearshore cod fisheries (based on Bycatch Collector data, and an important component of the overall estimate listed in Table 5) represents approximately $13.2 \%$ (95\% CI: 0 to $33.4 \%$ ) of the breeding population of 10000 pairs in the Cape St. Mary's colony. Such catch levels are likely unsustainable, especially in the event of increases in fishing effort (Davoren 2007). The use of gillnets along the northeast coast of Newfoundland has been limited since the closure of large-scale commercial cod fisheries in 1992, and most nearshore gillnets are now deployed along the south coast of the island, where few murre colonies occur. In 2006, a limited commercial fishery for cod was re-opened in nearshore waters along northeastern Newfoundland (DFO 2006). Although this fishery could lead to catches of diving seabirds, including murres, levels of fishing effort are not thought to be high enough to lead to declines in seabird populations. The lumpfish fishery may also catch considerable numbers of murres, due to its popularity among nearshore fishers and the overlap between the fishing season and the arrival of birds at breeding colonies (May to June); however, early start and end dates may reduce bycatch considerably. Based on limited Fishery Observer data, the offshore gillnet fisheries studied to date do not pose a significant risk to murres in Newfoundland and Labrador waters. Presently, bycatch in gillnet fisheries likely represents a relatively minor source of anthropogenic mortality for Newfoundland and Labrador murres, which are also impacted by oil pollution (Wiese \& Ryan 2003, Wiese \& Robertson 2004) and directed hunting (Chardine et al. 1999). However, when reviewing management plans for this species, all sources of mortality including bycatch in gillnets should be considered to determine whether current exploitation levels are sustainable.

The other potentially significant interaction between seabirds and gillnet fisheries occurs off the south coast of Newfoundland and involves various species of shearwaters. An estimated average total of $>2000$ shearwaters are captured annually in gillnet fisheries, although interannual variability is high (Table 5). Catches appear particularly high in the offshore cod fishery but also occur in fisheries for monkfish, skate, white hake and Greenland halibut. It is unknown how shearwaters get entangled in nets fishing for these latter species, as nets are typically set at depths of a hundred to several hundred meters, considered to be beyond the diving range of these birds (Keitt et al. 2000, Burger 2001). Some species, such as greater shearwater, often scavenge near fishing vessels and may become entangled in nets as they are being set or hauled (Piatt 1984, W. Montevecchi, Memorial University of Newfoundland, pers. comm.). This appears particularly likely if the hauling process takes time, and nets containing fish are suspended close to the surface near the fishing vessel. Further research is needed to assess this. It is unknown why catches are so variable between years, since shearwaters are regular summer and fall visitors to the area (Brown et al. 1975, Huettmann \& Diamond 2000).

An estimated 2 to 3 million shearwaters of various species occur seasonally in Newfoundland waters (mostly greater shearwaters; Brown et al. 1975, Montevecchi 2000). Bycatches of shearwaters reported here are unlikely to be high enough for immediate concern. However, migrating shearwater populations will likely experience sequential mortality in numerous different fisheries such as those in Newfoundland and Labrador waters (Huettmann \& Diamond 2000, Lewison et al. 2005). A detailed analysis of bycatch of these species in fisheries throughout the Atlantic is needed, as has been done in other areas (Uhlmann et al. 2005).

The ability to correctly identify seabirds is essential for accurate bycatch estimation, but not all reporters in this study appeared equally capable. Bycatch Collectors, in particular, did not distinguish common murres from thick-billed murres, commonly referring to both species as 'turrs'. The relative proportions of common and thick-billed murres in bycatch are unknown, but it is assumed that the majority of cases during the spring and summer of the year, when most of the fishing effort took place, involved common murres. It is also unknown how well Bycatch Collectors were able to distinguish other alcids from the common/thick-billed murre clade, particularly razorbills and-to a lesser extent-black guillemots. Similarly, not all shearwaters could be identified to species level by Fishery Observers. Dead shearwaters may be difficult to identify, particularly after having been entangled for some time. Based on previous surveys in the northwest Atlantic, most unidentified specimens were likely greater shearwaters (Brown et al. 1975, Mactavish et al. 2003).

For various logistical reasons, Fishery Observer coverage is limited or absent in several nearshore fisheries. Accurately recording relatively rare episodic mortality events such as bycatch of seabirds requires a high level of observer coverage that can only be achieved through considerable investment (Babcock et al. 2003). Data collected by selected fishers (such as the Bycatch Collector database) may be used to describe 
bycatch in these fisheries, but such data may suffer from lack of coverage in areas or fisheries where seabirds are at risk (e.g. the nearshore herring gillnet fishery). Expanding the Fishery Observer and Bycatch Collector programmes in these fisheries would be desirable, but appears unlikely in the immediate future. It is unknown what caused the discrepancy in bycatch rates of murres in Bycatch Collector and Fishery Observer data in the nearshore lumpfish fishery. Possible causes include low Fishery Observer coverage, the possibility that Fishery Observers did not observe all birds due to other responsibilities, and/or clustered distribution of murres (Davoren et al. 2003a). This emphasizes the importance of sufficient Observer coverage rates to accurately assess bycatch of seabirds.

Current levels of bycatch of seabirds in Newfoundland and Labrador gillnet fisheries appear relatively low, primarily due to low levels of fishing effort, although effects on specific colonies may be considerable. If fishing effort were to increase, the concomitant increase in seabird catches would have a greater impact on provincial seabird populations. Comprehensive management plans for species such as murres should incorporate this incidental mortality, and when necessary include measures to reduce its impact. Several such measures, such as time-area closures around breeding colonies, enhancing the detectability of nets, and changes in fishing methods or fishing gears, are already available and may be used to reduce bycatches in Newfoundland gillnet fisheries (Melvin et al. 1999, Walsh \& Hiscock 2005, Davoren 2007).

\section{CONCLUSIONS}

Despite changes in gillnet usage since the various fisheries closures in the early 1990s, current gillnet fisheries in Newfoundland and Labrador waters continue to catch various species of seabirds. Based on data for gillnet fisheries during the 2001 to 2003 fishing seasons, an estimated 5000 to 10000 murres, >2000 shearwaters of various species, several hundred loons, gannets, Atlantic puffins and black guillemots, and smaller numbers of other alcids, cormorants, fulmars, and eider ducks were captured in gillnets each year. Several sources of bias have negatively influenced these estimates, including problems with identification of different species, and low observer coverage of nearshore small-boat fisheries. Despite this, gillnet fisheries for cod, lumpfish, monkfish and skates, white hake and Greenland halibut appear responsible for most bycatch of seabirds in Newfoundland and Labrador.

Catch estimates of murres and shearwaters in Newfoundland waters are considered to be of potential concern. Populations of these species are not presently thought to be declining as a direct result of this incidental mortality; however, populations might be affected if gillnetting effort were to increase following fish stock recovery. Shearwaters' extensive migrations ensure sequential interactions with numerous fisheries throughout the north and south Atlantic, the cumulative effect of which may be significant. More information is required on the degree of overlap of these species with fisheries. Bycatch estimates should be incorporated in management plans for these seabird species, and mitigation efforts should be undertaken wherever necessary.

Acknowledgements. We thank the Bycatch Collectors and Fishery Observers who provided information on incidental takes of seabirds. We thank Sandra Savory and Anne-Marie Russell in Policy and Economics (DFO, NL), for access to their fishing effort and landings databases. Wayne Penney (DFO, NL) organized the Bycatch Collector programme. Joe Firth (DFO, NL) provided support in training observers, as well as information on at-sea observer activities. Mariano KoenAlonso (DFO, NL) provided valuable statistical advice for deriving approximations of confidence intervals. Financial support for this study was provided by Fisheries and Oceans Canada through its Species At Risk programme. Two anonymous reviewers provided helpful suggestions to further improve this manuscript.

\section{LITERATURE CITED}

Ainley DG, Nettleship DN, Carter HR, Storey AE (2002) Common murre (Uria aalge). In: Poole A, Gill F (eds) The birds of North America, No. 666. The Academy of Natural Sciences, Philadelphia, PA, and The American Ornithologists' Union, Washington, DC. Also available online at: http://bna.birds.cornell.edu/BNA/

Anonymous (2003) DFO-CWS National Working Group on Seabird Bycatch in Longline Fisheries. Status report and future directions towards the development of a National Plan of Action for the reduction of incidental catch of seabirds in domestic and foreign longline fisheries in Canadian waters. Can Tech Rep Fish Aquat Sci 2471

Babcock EA, Pikitch EK, Hudson CG (2003) How much observer coverage is enough to accurately estimate bycatch? Oceana and Pew Institute for Ocean Science Report. Available at: http://www.pewtrusts.org/ uploadedFiles/wwwpewtrustorg/Reports/Protecting_ ocean_life/oceana_bycatch_110403.pdf

Bakken V, Falk K (eds) (1998) Incidental take of seabirds in commercial fisheries in the arctic countries. Conservation of Arctic Flora and Fauna Technical Report No. 1. Arctic Council, Akureyri. 60 pp. Available online at: http:// arcticportal.org/uploads/IO/X9/IOX95YHnnSE580uhnymxQQ/ Technical-Rep.-no.1.pdf

Blank S, Seiter C, Bruce P (2001) Resampling stats in Excel, Version 2. Resampling Stats, Arlington, VA

Brothers NP, Cooper J, Løkkeborg S (1999) The incidental catch of seabirds by longline fisheries: worldwide review and technical guidelines for mitigation. FAO Fisheries Circular, Rome

Brown RGB, Nettleship DN, Germain P, Tull CE, Davis T (1975) Atlas of eastern Canadian seabirds. Canadian 
Wildlife Service Publication, Ottawa, ON

Burger AE (2001) Diving depths of shearwaters. Auk 118:755-759

Burger AE, Simpson M (1986) Diving depths of Atlantic puffins and common murres. Auk 103:828-830

Cairns DK (1992) Diving behavior of black guillemots in northeastern Hudson Bay. Colon Waterbirds 15:245-248

Cairns DK, Bredin KA, Montevecchi WA (1987) Activity budgets and foraging ranges of breeding common murres. Auk 104:218-224

Camphuysen CJ, Calvo B, Durinck J, Ensor K and others (1995) Consumption of discards by seabirds in the North Sea. Final Report of EC DG XIV Research Contract BIOECO/93/10. NIOZ-Report 1995-5. Netherlands Institute for Sea Research, Texel

Carretta JV, Price T, Petersen D, Read R (2004) Estimates of marine mammal, sea turtle, and seabird mortality in the California drift gillnet fishery for swordfish and thresher shark, 1996-2002. Mar Fish Rev 66:21-30

Chapdelaine G (1997) Pattern of recoveries of banded razorbills (Alca torda) in the western Atlantic and survival rates of adults and immatures. Colon Waterbirds 20:47-54

Chardine JW, Collins BT, Elliot RD, Levesque H, Ryan PC (1999) Trends in the annual harvest of murres in Newfoundland and Labrador. Bird Trends 7:11-14

Chardine JW, Porter JM, Wohl KD (eds) (2000) Workshop on seabird incidental catch in the waters of Arctic countries. Report and recommendations. Conservation of Arctic Flora and Fauna Technical Report No. 7. Arctic Council, Akureyri

Cooper J, Dunn E, Kulka DW, Morgan K, Rivera KS (2000) Addressing the problem: seabird mortality from longline fisheries in the waters of Arctic countries. In: Chardine JW, Porter JM, Wohl KD (eds) Workshop on seabird incidental catch in the waters of Arctic Countries. Conservation of Arctic Flora and Fauna Technical Report No. 7. Arctic Council, Akureyri

CWS (Canadian Wildlife Service) (2004) Population status of migratory game birds in Canada (and regulation proposals for overabundant species) — November 2004. Canadian Wildlife Service Report. Available online at: www.cwsscf.ec.gc.ca/publications/status/nov04/cont_e.cfm

Davoren GK (2007) Effects of gill-net fishing on marine birds in a biological hotspot in the northwest Atlantic. Conserv Biol 21:1032-1045

> Davoren GK, Montevecchi WA, Anderson JT (2003a) Distributional patterns of a marine bird and its prey: habitat selection based on prey and conspecific behaviour. Mar Ecol Prog Ser 256:229-242

Davoren GK, Montevecchi WA, Anderson JT (2003b) Search strategies of a pursuit-diving marine bird and the persistence of prey patches. Ecol Monogr 73:463-481

DFO (Department of Fisheries and Oceans) (2006) New government programme to test the health of cod stocks. Department of Fisheries and Oceans News Release. Available online at: www.dfo-mpo.gc.ca/media/newsrel/2006/ hq-ac14_e.htm

FAO (Food and Agriculture Organization of the United Nations) (1999) International Plan of Action for reducing incidental catch of seabirds in longline fisheries. Food and Agriculture Organisation (FAO), Rome. Available online at: www.fao.org/fishery/ipoa-seabirds/en

Furness RW (2003) Impacts of fisheries on seabird communities. Sci Mar 67(Suppl 2):33-45

Gilman E, Brothers N, Kobayashi DR (2005) Principles and approaches to abate seabird by-catch in longline fisheries. Fish Fish 6:35-49
Huettmann F, Diamond AW (2000) Seabird migration in the Canadian northwest Atlantic ocean: moulting locations and movement patterns of immature birds. Can J Zool 78:624-647

Hutchings JA, Myers RA (1995) The biological collapse of Atlantic cod off Newfoundland and Labrador: an exploration of historical changes in exploitation, harvesting technology, and management. In: Arnason R, Felt L (eds) The North Atlantic fisheries: successes, failures and challenges. The Institute of Island Studies, Charlottetown, PEI, p $37-93$

Jury JA (1986) Razorbill swimming at depth of 140 m. Br Birds 79:339

> Keitt BS, Croll DA, Tershy BR (2000) Dive depth and diet of the black-vented shearwater (Puffinus ophistomelas). Auk 117:507-510

Kulka DW, Firth JR (1987) Observer program training manual - Newfoundland region. Can Tech Rep Fish Aquat Sci 1355 (revised)

Kulka DW, Showell M (2000) Seabird bycatch on longline fisheries in Atlantic Canada. In: Chardine JW, Porter JM, Wohl KD (eds) Workshop on seabird incidental catch in the waters of Arctic countries. Conservation of Arctic Flora and Fauna Technical Report No. 7. Arctic Council, Akureyri, p 19

Lewison RL, Nel DC, Taylor F, Croxall JP, Rivera KS (2005) Thinking big — taking a large-scale approach to seabird bycatch. Mar Ornithol 33:1-5

Lowther PE, Diamond AW, Kress SW, Robertson GJ, Russell K (2002) Atlantic puffin (Fratercula arctica). In: Poole A, Gill F (eds) The birds of North America, No. 709. The Academy of Natural Sciences, Philadelphia, PA, and The American Ornithologists' Union, Washington, DC. Available online at: http://bna.birds.cornell.edu/BNA/.

Mactavish B, Maunder JE, Montevecchi WA, Wells JL, Fifield DA (2003) Checklist of the birds of insular Newfoundland and its continental shelf waters. The Natural History Society of Newfoundland and Labrador, St. John's, NL. Available online at: www.nhs.nf.ca/cbc_etc/checklist.htm

Melvin EF, Parrish JK, Conquest LL (1999) Novel tools to reduce seabird bycatch in coastal gillnet fisheries. Conserv Biol 13:1386-1397

Montevecchi WA (2000) Seabirds. In: Bundy A, Lilly GR, Shelton PA (eds) A mass balance model of the Newfoundland-Labrador Shelf. Can Tech Rep Fish Aquat Sci 2310, p 15-18

Montevecchi WA (2001) Interactions between fisheries and seabirds. In: Burger J (ed) The biology of marine birds. CRC Press, Boca Raton, FL, p 527-557

Montevecchi WA, Stenhouse IJ (2002) Dovekie (Alle alle). In: Poole A, Gill F (eds) The birds of North America, No. 701. The Academy of Natural Sciences, Philadelphia, PA, and The American Ornithologists' Union, Washington, DC. Available online at: http://bna.birds.cornell.edu/BNA/

Montevecchi WA, Tuck LM (1987) Newfoundland birds: exploitation, tudy and conservation. Nuttall Ornithological Club, Cambridge, MA

Österblom H, Fransson T, Olsson O (2002) Bycatches of common guillemot (Uria aalge) in the Baltic Sea gillnet fishery. Biol Conserv 105:309-319

Piatt J (1984) Net mortality of marine birds in Newfoundland, 1981-82. Report No. 136, Seabird Research Unit, Canadian Wildlife Service, Bedford Institute of Oceanography, Dartmouth, NS

Piatt JF, Nettleship DN (1985) Diving depths of four alcids. Auk 102:293-297

Piatt JF, Nettleship DN (1987) Incidental catch of marine birds 
and mammals in fishing nets off Newfoundland, Canada. Mar Pollut Bull 18:344-349

Piatt JF, Nettleship DN, Threlfall W (1984) Net-mortality of common murres and Atlantic puffins in Newfoundland, 1951-81. In: Nettleship DN, Sanger GA, Springer PF (eds) Marine birds: their feeding ecology and commercial fisheries relationships. Supply and Services Canada, Ottawa, ON, p 196-206

Robertson GJ, Wilhelm SI, Taylor PA (2004) Population size and trends of seabirds breeding on Gull and Great Islands, Witless Bay Islands Ecological Reserve, Newfoundland, up to 2003. Can Wildl Serv Tech Rep Ser (Atlantic Region) 418

Sinclair AF, Murawski SA (1997) Why have groundfish stocks declined? In: Boreman J, Nakashima BS, Wilson JA, Kendall RL (eds) Northwest Atlantic groundfish: perspectives on a fishery collapse. American Fisheries Society, Bethesda, MD, 71-94

Snow DA (1996) A self-driving guide: seabirds. Department of Tourism, Culture and Recreation, Government of Newfoundland and Labrador, St. John's, NL

Tasker ML, Camphuysen CJ, Cooper J, Garthe S, Montevecchi WA, Blaber SJM (2000) The impacts of fishing on

Editorial responsibility: Rebecca Lewison,

San Diego, California, USA marine birds. ICES J Mar Sci 57:531-547

> Tuck GN, Polachek T, Bulman CM (2003) Spatio-temporal trends of longline fishing effort in the Southern Ocean and implications for seabird bycatch. Biol Conserv 114:1-27

Uhlmann S, Fletcher D, Moller H (2005) Estimating incidental takes of shearwaters in driftnet fisheries: lessons for the conservation of seabirds. Biol Conserv 123:151-163

Walsh PJ, Hiscock W (2005) Fishing for Atlantic cod (Gadus morhua) using experimental baited pots. Results from trials in Placentia Bay \& Fortune Bay, December 2003 \& 2004, Newfoundland and Labrador, Canada. Report P-56. Centre for Sustainable Aquatic Resources, Fisheries \& Marine Institute, Memorial University of Newfoundland, St. John's, NL

Wiese FK, Robertson GJ (2004) Assessing seabird mortality from chronic oil discharges at sea. J Wildl Manag 68:627-638

Wiese FK, Ryan PC (2003) The extent of chronic marine oil pollution in southeastern Newfoundland waters assessed through beached bird surveys 1984-1999. Mar Pollut Bull 46:1090-1101

Submitted: July 25, 2007; Accepted: March 27, 2008

Proofs received from author(s): June 8, 2008 